\title{
Penerapan Model Pembelajaran Ropes dan Pengetahuan Awal Terhadap Hasil Belajar Perkuliahan Matematika Di Stikes Prima Nusantara
}

\author{
Yoko Masna Rivan. M $^{1)}$ Yeffi Masnarivan ${ }^{2)}$ \\ ${ }^{1)}$ Dosen Prodi D-IV Bidan Pendidik, STIKes Prima Nusantara \\ ${ }^{2)}$ Dosen Prodi Kesehatan Masyarakat, STIKes Prima Nusantara \\ yokomasnarivanm@gmail.com
}

\begin{abstract}
This research is based on the low level of mathematics lecture result, which is caused by the learning that is still dominated by the lecturers so that the students are less motivated and bored with the learning activities in the lectures. Lecturers have not been able to encourage students to develop the talents and skills of individual students, and still many students who have not been able to formulate their own hypothesis. learning that is not optimal yet it is necessary efforts to improve learning outcomes math lectures. This study aims to reveal the effect of ROPES learning model and initial knowledge on mathematics learning outcomes in STIKes Prima Nusantara. The research design used was Randomized Group Only Design. The population of this study is all students STIKes Prima Nusantara level I of the academic year 2017-2018. Data were collected through initial knowledge tests and and learning result tests. The results revealed that the results of lectures of students who were taught with ROPES learning model higher than the results of student learning taught by conventional learning model, student learning outcomes that have a high initial knowledge with ROPES learning model higher than the results of learning mathematics students who have a high initial knowledge with conventional learning model, student learning outcomes that have low initial knowledge with ROPES learning model higher than the results of mathematics learning students who have low initial knowledge with conventional learning model and there is no interaction between learning models and knowledge early in influencing the results of college mathematics students STIKes Prima Nusantara.
\end{abstract}

Keywords : Learning outcomes, Initial knowledge, Learning models

This is an open access article distributed under the Creative Commons 4.0 Attribution License, which permits unrestricted use, distribution, and reproduction in any medium, provided the original work is properly cited $@ 2018$ by author and Universitas Negeri Padang.

\section{PENDAHULUAN}

Perkuliahan matematika merupakan pro ses pemberian pengalaman belajar kepada peserta didik melalui serangkaian kegiatan yang terencana sehingga peserta didik memperoleh kompetensi tentang materi yang akan dipelajari. Menurut Hudojo (1990), matematika merupakan suatu bahan kajian yang memiliki objek abstrak dan dibangun melalui proses penalaran deduktif, yaitu kebenaran suatu konsep diperoleh sebagai akibat logis dari kebenaran sebelumnya sudah diterima, sehingga keterkaitan antar konsep dalam matematika bersifat sangat kuat dan jelas.

Berdasarkan hasil pengamatan dan penga laman, perkuliahan matematika masih didomi nasi oleh dosen. Hal ini mengakibatkan ma hasiswa kurang aktif selama pembelajaran. Keadaan lain yang tampak banyak mahasiswa yang tidak mengerjakan tugas dengan baik. Mahasiswa membuat tugas hanya untuk meng hindari hukuman dari dosen. Ketika dosen menyuruh mahasiswa untuk mengerjakan latihan atau soal ke depan kelas, tidak banyak dari mereka yang mau menawarkan diri untuk mengerjakannya. Tidak terlihat bahwa maha siswa lain juga mengerti mengenai materi perkuliahan yang telah disampaikan oleh dosen. Di sisi lain, banyak mahasiswa yang kurang termotivasi dan jenuh dengan kegiatan per kuliahan yang dilaksanakan. Hal ini terlihat banyaknya mahasiswa yang keluar masuk saat perkuliahan berlangsung, mengantuk, dan maha siswa akan mencatat materi yang telah disam paikan dosen hanya ketika disuruh.

Dosen kurang mampu mendorong maha siswa untuk mengembangkan bakat, kecakapan individu dan dalam merumuskan hipotesis sendiri. Hal ini dapat dilihat ketika mahasiswa disuruh mencari hubungan yang berlaku antara $d$, titik $P$, dan garis $g$ pada materi geometri. Dari $d$ sebagai jarak titik $P=\left(x_{1}, y_{1}\right)$ ke garis $g \equiv a x+b y+c=0$, maka didapat rumus 
$d=\left|\frac{a x_{1}+b y_{1}+c}{\sqrt{a^{2}+b^{2}}}\right|$. Untuk titik $P$ dan garis $g$, mahasiswa lebih banyak diam dan tidak bisa menjawab pertanyaan yang diberikan. Keadaan lain yang tampak dengan banyaknya mahasiswa yang tidak mau menyampaikan pendapat dan malas bertanya mengenai materi perkuliahan yang kurang mereka pahami ketika pem belajaran berlangsung. Hal itu juga menjadi faktor yang bisa menyebabkan hasil belajar yang diperoleh mahasiswa kurang memuaskan sehingga tujuan pembelajaran tidak tercapai.

Kegiatan perkuliahan yang lebih menarik akan membuat mahasiswa berpartisipasi aktif karena perkuliahan yang berlangsung tidak terkesan membosankan lagi. Di mana, selama ini penulis mengkategorikan bahwa perkuliahan yang berlangsung di STIKes Prima Nusantara termasuk pembelajaran konvensional karena pada pelaksanaannya lebih menekankan pada peranan dosen sebagai pemberi informasi tanpa memperhatikan kegiatan mahasiswa selama perkuliahan berlangsung. Sedangkan dalam melakukan penilaian, hanya dilihat berdasarkan hasil tes yang diperoleh mahasiswa, bukan pada saat menjalani proses belajar.

Penggunaan model pembelajaran serta pendekatan yang sesuai dengan kondisi mahasiswa mampu memberikan alternatif keberhasilan perkuliahan matematika. Salah satu bentuk pembelajaran yang bisa dilaksanakan adalah model pembelajaran ROPES (Review, Overview, Presentation, Exercise, Summary). Model pembelajaran ini diharapkan mampu meningkatkan aktivitas mahasiswa selama perkuliahan matematika. Mahasiswa tidak hanya berperan sebagai penerima informasi yang diberikan oleh dosen. Mereka akan berusaha mencari informasi sebanyak-banyaknya, kemu dian bisa mereka sampaikan melalui kegiatan presentasi. Memiliki pengetahuan awal sangat penting dalam pembelajaran dengan metode ROPES. Mahasiswa mustahil dapat melalui kegiatan Review, Overview, Presentation, Exercise, Summary sekiranya tidak memiliki pengetahuan awal yang berkenaan.

Pengetahuan awal merupakan pengeta huan yang dimiliki mahasiswa tentang materi dasar sebagai prasyarat dalam mempelajari materi yang baru. Pengetahuan awal ini disebut juga skema kognitif yang tersimpan dalam memori jangka panjang sebagai landasan data. Klausmeir (1985) pengetahuan awal seseorang disebut juga skemata atau struktur kognitif yang tersimpan dalam memori jangka panjang sebagai data. Memori tidak hanya oleh informasi yang disajikan, tetapi juga oleh pengetahuan awal yang relevan. Oleh karena itu, jika mahasiswa memiliki pengetahuan awal yang bagus maka kegiatan Review, Overview, Presentation, Exercise, Summary akan dilaksanakan dengan maksimal.

Tujuan dari penelitian ini adalah menge tahui hasil belajar perkuliahan matematika mahasiswa yang diajarkan dengan model pembelajaran ROPES dengan hasil belajar perkuliahan matematika mahasiswa yang diajar dengan model pembelajaran konvensional, Mengetahui interaksi antara model pembelajaran dan pengetahuan awal dalam mempengaruhi hasil belajar mahasiswa, Mengetahui hasil belajar perkuliahan matematikamaha siswa dengan pengetahuan awal tinggi yang diajar dengan model pembelajaran ROPES dengan hasil belajar perkuliahan matematika mahasiswa dengan pengetahuan awal tinggi yang diajar dengan model pembelajaran konvensional, dan Mengetahui hasil belajar perkuliahan mate matika mahasiswa dengan pengetahuan awal rendah yang diajar dengan model pembelajaran ROPES dengan hasil belajar perkuliahan mahasiswa dengan pengetahuan awal rendah yang diajar dengan model pembelajaran konvensional

Belajar merupakan suatu proses peru bahan tingkah laku berkat pengalaman dan latihan, artinya tujuan dari kegiatan belajar ini adalah terjadinya perubahan tingkah laku, baik yang menyangkut pengetahuan, keterampilan maupun sikap, bahkan meliputi segenap aspek pribadi. Sebagaimana yang dinyatakan oleh Slameto (2010:2) bahwa: "Belajar ialah suatu proses usaha yang dilakukan seseorang untuk memperoleh suatu perubahan tingkah laku yang baru secara keseluruhan, sebagai hasil pengalamannya sendiri dalam interaksi dengan lingkungannya".

Nikson (Muliyardi, 2002:3) mengemu kakan bahwa: "Pembelajaran matematika adalah upaya membantu siswa untuk mengkontruksi konsep-konsep atau prinsip-prinsip matematika dengan kemampuannya sendiri melalui proses internalisasi sehingga konsep atau prinsip itu terbangun kembali".

Pembelajaran matematika memerlukan konsepsi yang cukup terstruktur dan terarah. Dimaksudkan bahwa dalam belajar mata kuliah matematika mahasiswa dituntut untuk dapat 
mengaitkan simbol-simbol dan mengaplikasikan konsep-konsep tersebut dalam situasi nyata. Salah satu upaya yang dapat dilakukan dosen yaitu dengan menggunakan model dan strategi pembelajaran yang tepat pada perkuliahan agar tujuan pembelajaran dapat tercapai.

Berdasarkan penjelasan di atas dapat disimpulkan bahwa proses perkuliahan terjadi secara bersamaan, yaitu melibatkan komponenkomponen model dan strategi pembelajaran yang saling mempengaruhi satu sama lain. Menerapkan model atau strategi pembelajaran yang menarik bertujuan agar peserta didik menguasai pengetahuan, sikap, dan keteram pilan tentang matematika sehinggamenghasilkan perubahan-perubahan tingkah laku yang bersifat permanen.

Ali (2008: 74) mengemukakan bahwa entering behavior atau pengetahuan awal pada dasarnya merupakan keadaan pengetahuan dan keterampilan yang harus dimiliki terlebih dahulu oleh mahasiswa sebelum ia mempelajari pengetahuan dan keterampilan yang baru. Pengetahuan yang dimiliki mahasiswa bersifat individual. Untuk menngetahuinya harus secara individual juga. Entering behavior dapat juga disebut dengan kesiapan (readiness). Ausubel dalam Ali (2008: 75) mengartikan readiness sebagai keadaan kapasiti (kemampuan potensial) siswa secara memadai dalam hubungannya dengan pengajaran.

Melalui pengetahuan awal mahasiswa, dosen dapat menetapkan dari mana harus memulai pembelajaran. Ada tiga dimensi dari entri behavior yang perlu diketahui oleh dosen sebagaimana yang dinyatakan Djamarah (2006) yakni 1) batas-batas ruang lingkup materi pengetahuan yang telah dimiliki dan dikuasai oleh mahasiswa; 2) tingkatan tahapan materi pengetahuan, terutama kawasan pola-pola sambutan atau kemampuan yang telah dimiliki mahasiswa; 3) kesiapan dan kematangan fungsifungsi psikofisik.

Pengetahuan awal dalam penelitian ini adalah kemampuan dasar yang sudah ada pada mahasiswa secara memadai dalam hubungannya dengan tujuan pembelajaran yang dapat di kembangkan melalui proses pembelajaran. Dengan kata lain, pengetahuan awal adalah kemampuan dasar mahasiswa dalam memahami suatu materi pembelajaran dan merupakan pengetahuan yang telah dimiliki atau penge tahuan yang sudah ada pada mahasiswa sebelum materi tersebut dipelajari atau diajarkan kepadanya pada perkuliahan.

Model pembelajaran ROPES bersifat mengembangkan dan memberdayakan kemam puan peserta didik dalam mencari, menemukan sumber, dan meramu materi dalam bentuk hasil kajian yang selanjutnya dapat disajikan di kelas, serta membuka ruang bagi diskusi sebagai bagian dari pertanggungjawaban tugas yang dilanjutkan dengan koreksi penyempurnaan oleh dosen sebagai fasilitator dalam pembelajaran.

Menurut Hunts dalam Madjid (2013), model pembelajaran ROPES tidak mengka tegorikan perencanaan pengajaran menjadi rencana semester, mingguan, dan harian. Hunts lebih mendefinisikan model pembelajaran ROPES mengikuti langkah-langkah pelaksanaan pembelajarannya sebagai berikut: 1) Review, kegiatan ini dilakukan dalam waktu 1 sampai 5 menit, tujuannya untuk mengukur kesiapan mahasiswa mempelajari bahan perkuliahan dengan melihat pengalaman sebelumnya yang sudah dimiliki oleh mahasiswa dan diperlukan sebagai prerequisite (prasyarat) untuk memahami bahan yang disampaikan hari itu. Dosen harus yakin dan tahu betul jika mahasiswa sudah siap menerima materi baru. Jika mahasiswa belum menguasai materi sebelumnya, maka dosen harus dengan bijak memberi kesempatan kepada mahasiswa untuk memahaminya terlebih dahulu atau mengi ngatkan melalui pemberian tugas, penjelasan, bimbingan, tutor sebaya, dan baru bergerak pada materi selanjutnya. 2) Overview, sebagaimana review, overview dilakukan berkisar antara 2 sampai 5 menit. Dosen menjelaskan program perkuliahan yang akan dilaksanakan pada hari itu dengan menyampaikan isi (content) secara singkat dan strategi yang akan digunakan dalam proses pembelajaran. Hal ini dimaksudkan untuk memberikan kesempatan kepada mahasiswa untuk menyampaikan pandangannya atas langkah-langkah pembelajaran yang hendak ditempuh oleh dosen sehingga berlangsungnya proses pembelajaran bukan hanya milik dosen semata, akan tetapi mahasiswa pun ikut merasa senang dan merasa dihargai keberadaannya. 3 ) Presentation, merupakan inti dari proses kegiatan belajar mengajar dalam perkuliahan, karena disini dosen tidak lagi memberikan penjelasan-penjelasan singkat, akan tetapi sudah masuk pada proses telling, showing, dan doing. Proses ini sangat diperlukan untuk mening katkan daya serap dan daya ingat mahasiswa 
tentang pelajaran yang mereka dapatkan. Hal ini sejalan dengan yang dikemukakan Amin (2004) bahwa ilmu akan lebih mudah dipahami jika diajarkan kepada orang lain. Semakin bervariasi strategi pembelajaran dalam perkuliahan, semakin baik proses dan hasil yang dicapai, karena tidak menjadikan mahasiswa jenuh, melainkan mengantarkan mereka menikmati proses pembelajaran dengan suasana asyik dan menyenangkan. 4) Exercise, merupakan proses untuk memberikan kesempatan kepada mahasiswa mempraktekkan apa yang telah mereka pahami.Hal ini dimaksudkan untuk memberikan pengalaman langsung kepada mahasiswa sehingga hasil yang dicapai lebih bermakna. Oleh karena itu dosen harus mempersiapkan rencana perkuliahan tersebut dengan baik melalui skenario yang sistematis, dan 5) Summary, bertujuan untuk memperkuat apa yang telah mereka pahami dalam proses pembelajaran. Kegiatan ini sering tertinggal oleh dosen karena mereka disibukkan dengan presentase, dan bahkan mungkin dosen tidak pernah membuat summary (kesimpulan) dari apa yang telah mereka ajarkan.

Penelitian ini memodifikasi dengan me nambahkan pembuatan ringkasan mengenai materi yang akan dipelajari oleh mahasiswa. Ringkasan ini berguna nantinya sebagai bahan pada kegiatan Presentation. Pada kegiatan Presentation, penulis juga menambahkan adanya lot kotak 1 dan kotak 2 yang masingmasing terdapat nama mahasiswa yang akan melakukan presentasi dan nama mahasiswa yang akan bertanya kepada mahasiswa yang mela kukan presentasi. Hal ini dikarenakan agar penerapan model pembelajaran ROPES dapat membantu meningkatkan aktivitas dan motivasi mahasiswa dalam mempelajari mata kuliah matematika sehingga diharapkan dapat mening katkan hasil belajar mata kuliah matematika mahasiswa.

Model pembelajaran konvensional meru pakan perkuliahan yang biasa dilakukan oleh dosen dalam mengajarkan mata kuliah mate matika selama ini. Konvensional dalam Kamus Besar Bahasa Indonesia berarti "Pemufakatan atau kelaziman atau sesuatu yang telah menjadi kebiasaan". Menurut Sanjaya (2006: 259), pada pembelajaran konvensional mahasiswa ditem patkan sebagai objek belajar yang berperan sebagai penerima informasi secara pasif. Pada model pembelajaran konvensional, guru meng gunakan komunikasi satu arah di mana infor masi yang dijelaskan kepada siswa secara lisan. Dalam model pembelajaran konvensional, dosen cenderung aktif sebagai sumber informasi bagi mahasiswa dan siswa cenderung pasif dalam menerima pembelajaran.

Cara lain dari pelaksanaan model pem belajaran konvensional ini adalah mahasiswa sekaligus mengerjakan dua kegiatan, yaitu mendengarkan dan mencatat. Di samping itu, model pembelajaran konvensional sangat sesuai jika diterapkan di ruangan terbatas, dan tenaga pengajar kurang memenuhi kebutuhan. Hal ini sejalan dengan yang dikemukakan Sagala (2011) menyatakan bahwa pembelajaran konvensional diartikan sebagai pembelajaran dalam konteks klasikal yang sudah terbiasa dilakukan, sifatnya berpusat pada guru, sehingga pelaksanaanya kurang memperhatikan keseluruhan situasi belajar.

Berdasarkan kutipan di atas, dapat disim pulkan bahwa pelaksanaan model pembelajaran konvensional lebih menekankan pada peranan dosen sebagai pemberi informasi dengan sedikit memperhatikan kegiatan siswa selama pem belajaran berlangsung. Dosen merupakan sum ber belajar yang dominan, dosen lebih banyak menggunakan waktunya di kelas untuk menyam paikan materi, dan pelaksanaan kegiatan pembelajaran lebih bersifat penyampaian informasi atau pengetahuan dalam bentuk ceramah sehingga mahasiswa menjadi lebih pasif dalam mengkonstruksi pengetahuannya. Sedangkan dalam melakukan penilaian hanya dilihat berdasarkan hasil tes yang diperoleh mahasiswa, bukan pada saat mahasiswa menjalani proses belajar.

Perkuliahan yang terlaksana di STIKes Prima Nusantara memiliki ciri yang sama dengan teori yang dikemukakan. Dengan demikian, perkuliahan yang terlaksana di STIKes Prima Nusantara tersebut diistilahkan dengan model pembelajaran konvensional.

\section{METODE PENELITIAN}

Rancangan penelitian yang digunakan adalah Randomized Control Group Only Design, sesuai dengan pendapat Soemadi (2005:104). Penelitian ini dilakukan di STIKes Prima Nusantara pada semester ganjil tahun ajaran 2017-2018. Populasi dalam penelitian ini adalah seluruh mahasiswa STIKes Prima Nusantara tingkat 1 yang terdaftar pada tahun ajaran 20172018. Adapun langkah penarikan sampel dalam 
penelitian ini adalah mengumpulkan nilai ujian harian pada semester ganjil matematika mahasiswa STIKes Prima Nusantara, melakukan uji normalitas dengan menggunakan uji Anderson-Darling dengan bantuan Software Minitab. Menurut Syafriandi (2001: 4) “Jika PValue yang diperoleh lebih kecil dari taraf nyata yang ditetapkan $(\alpha)$, maka tolak $\mathrm{H}_{0}$, dan sebaliknya kita terima $\mathrm{H}_{0}$ ". Setelah dilakukan Uji Normalitas, didapat bahwa semua kelas populasi memiliki P-Value yang lebih besar dari $\alpha$ yang ditetapkan yaitu 0,05 . Jadi, semua kelas populasi berdistribusi normal. Selanjutnya, melakukan uji homogenitas variansi dengan menggunakan uji Bartlett. Menurut Syafriandi (2001: 5) "Jika irisan selang kepercayaan itu kosong, maka dikatakan bahwa kelompok perlakuan tersebut tidak homogen, dan seba liknya dikatakan homogen". Setelah dilakukan uji homogenitas terdapat irisan pada tiap-tiap selang kepercayaan. Sehingga dapat disim pulkan bahwa data populasi mempunyai variansi yang homogen. Uji yang terakhir adalah mela kukan analisis variansi. Pengujian hipotesis ini dilakukan dengan bantuan Software Minitab. Untuk interpretasi uji ini dapat diperhatikan PValue. Setelah dilakukan uji hipotesis, berda sarkan hasil analisis uji kesamaan rata-rata populasi diperoleh bahwa P-Value lebih besar dari taraf nyata, sehingga dapat disimpulkan bahwa data populasi memiliki kesamaan ratarata.

Berdasarkan analisis uji di atas, maka pengambilan sampel dilakukan secara acak. Pengambilan pertama sebagai kelas eksperimen, yang terambil adalah program studi (kelas) kesehatan masyarakatyang selanjutnya disebut kelas 1 dan pengambilan kedua sebagai kelas kontrol, yang terambil adalah program studi (kelas) keperawatan yang selanjutnya disebut kelas 2.

Untuk mencapai tujuan penelitian yang telah ditetapkan, perlu disusun prosedur yang sistematis. Tahap persiapan pada penelitian ini merupakan tahapan mempersiapkan segala sesuatu yang berhubungan dengan pelaksanaan. Tahapan ini diawali dengan tes pengetahuan awal melalui pre-test. Setelah melakukan pengelompokan hasil tes pengetahuan awal, dilakukan penyusunan instrumen penelitian.

Pelaksanaan penelitian untuk kelas eksperimen dalam hal ini terdiri dari pendahuluan, kegiatan ini meliputi review antara lain dosen menyampaikan apersepsi dan memotivasi mahasiswa dan mengukur kesiapan mahasiswa untuk mempelajari materi pada pertemuan hari itu dan mengaitkan materi pelajaran sebelumnya melalui pemberian pertanyaan-pertanyaan mengenai materi yang telah dipelajari pada pertemuan sebelumnya. Adapun overview dalam penelitian ini meliputi penjelasan program perkuliahan yang akan dilaksanakan dan poin-pin yang menjadi pokok bahasan pada saat itu dan strategi yang akan digunakan selama perkuliahan berlangsung.

Kegiatan inti dalam penelitian ini terdiri dari presentation yang meliputi dosen mengum pulkan ringkasan materi yang telah dibuat mahasiswa di rumah, menceknya, kemudian mengembalikan kepada mahasiswa. Setelah itu, mengeluarkan dua buah kotak berisi lot mahasiswa. Kedua kotak dibedakan dengan memberikan tanda kotak I untuk siswa yang akan presentasi, dan kotak II untuk mahasiswa yang akan mengajukan pertanyaan. Kemudian dosen mencabut lot dari kotak pertama untuk mahasiswa yang akan melakukan presentasi dan meminta mahasiswa yang tercabut lotnya untuk mempresentasikan materi pelajaran di depan kelas secara bergantian. Setiap pertemuan hanya 2-3 orang mahasiswa yang akan melakukan presentasi. Setiap mahasiswa diberikan waktu 510 menit untuk mempresentasikan materi. Setelah kegiatan presentasi berlangsung, dosen mencabut lot mahasiswa yang akan mengajukan pertanyaan. Satu mahasiswa memberikan satu pertanyaan kepada salah satu mahasiswa yang tampil. Mahasiswa lain memberikan pertanyaan kepada mahasiswa yang lain juga. Mahasiswa yang tampil menjawab pertanyaan yang diajukan siswa lain yang tercabut lotnya. Jika ada pertanyaan mahasiswa yang belum terjawab, maka pertanyaan tersebut akan diselesaikan oleh dosen pada kegiatan summary. Jika masih ada mahasiswa yang ingin bertanya atau menge luarkan pendapat, dosen memberikan kesem patan untuk kegiatan tersebut. Selanjutnya exer cise yang bertujuan memberikan kesempatan kepada seluruh mahasiswa untuk menyelesaikan soal-soal yang telah dipersiapkan dosen mengenai materi yang telah dipresentasikan. Dosen memberikan beberapa buah soal latihan untuk dikerjakan mahasiswa.

Pada kegiatan penutup, terdiri dari summary yang meliputi Pertanyaan yang belum terjawab pada kegiatan presentasi akan dijelaskan kembali oleh dosen, dan mengulang mengulang kembali poin-poin yang telah 
dijelaskan mahasiswa pada saat presentasi. Hal tersebut dilakukan agar mahasiswa mendapat penguatan atas apa yang telah mereka ketahui. Dosen juga mengingatkan agar mahasiswa mencari, meringkas, dan memahami materi baru dirumah yang akan dibahas dan dipresentasikan pada pertemuan berikutnya.

Instrumen yang digunakan dalam penelitian ini adalah tes akhir belajar. Soal untuk tes akhir dibuat dalam bentuk essay. Sebelum soal tes digunakan dalam penelitian ini, terlebih dahulu dilakukan uji validitas isi. Validitas isi digunakan untuk menentukan seberapa jauh instrumen telah menggambarkan isi terpenuhi, selanjutnya dilakukan uji soal tes kepada mahasiswa yang kemampuannya setara dengan kemampuan mahasiswa sampel. Uji coba instrumen dilakukan untuk melihat validitas butir tes, daya pembeda butir tes, tingkat kesukaran butir tes, dan reliabilitas tes.

Untuk analisis validitas, dapat dilakukan dengan analisis faktor, yaitu mengkorelasikan antara skor butir soal dengan skor total. Menurut Suharsimi (2008), untuk menentukan koefisien korelasi tersebut digunakan rumus korelasi product momen pearson. Setelah dilakukan analisis, dapat disimpulkan valid untuk setiap butir soal.

Daya pembeda soal merupakan kemam puan soal untuk membedakan mahasiswa yang pandai dengan mahasiswa yang kurang pandai. Melihat daya pembeda soal, sebagaimana menggunakan rumus sesuai dengan yang dijelaskan Depdiknas (2001:27). Berdasarkan hasil perhitungan daya pembeda soal, dapat disimpulkan semua soal tes mempunyai daya pembeda baik.

Tingkat kesukaran soal digunakan untuk menunjukkan butir soal mudah, sedang, atau sukar. Soal yang baik adalah soal yang tidak terlalu mudah atau tidak terlalu sukar. Agar tes dapat digunakan secara luas, setiap soal harus diselidiki tingkat kesukarannya. Mengukur tingkat kesukaran soal pada penelitian ini menggunakan rumus yang dikemukakan oleh Depdiknas (2001:26), sehingga dari hasil perhitungan didapat sebanyak 11 soal tergolong sedang dan 1 soal tergolong mudah.

Reliabilitas tes merupakan ukuran apakah tes tersebut dapat dipercaya atau tidak. Menentukan reliabilitas dengan menggunakan rumus alpha yang dikemukakan Suharsimi (2010:109). Dari perhitungan didapat kesim pulan bahwa soal tes memiliki reliabilitas yang tinggi.

\section{HASIL DAN PEMBAHASAN}

Model pembelajaran ROPES dianalisis melalui melalui data hasil belajar perkuliahan matematika diakhir pemberian tindakan. Namun, sebelumnya data tersebut diujikan untuk mengetahui uji homogenitas variansi dan kenormalan datayang kemudian dilanjutkan dengan analisis data untuk mengetahui adanya pengaruh hasil belajar perkuliahan matematika dengan menggunakan model pembelajaran ROPES dan pengetahuan awal di STIKes Prima Nusantara. Setelah dilaksanakan tes akhir belajar mahasiswa, diperoleh pada Tabel 1 .

Tabel 1. Deskripsi Statistik Hasil Belajar Mahasiswa

\begin{tabular}{|l|c|c|}
\hline \multicolumn{1}{|c|}{ Statistik } & $\begin{array}{c}\text { Kelas } \\
\text { Eksperimen }\end{array}$ & $\begin{array}{c}\text { Kelas } \\
\text { Kontrol }\end{array}$ \\
\hline Skor Tertinggi & 100 & 100 \\
\hline Skor Terendah & 65 & 55 \\
\hline Standar Deviasi & 10,71 & 10,68 \\
\hline Mean & 80,74 & 70,56 \\
\hline
\end{tabular}

Adapun nilai rata-rata hasil belajar perkuliahan matematika mahasiswa yang diajar dengan model pembelajaran ROPES dari kelompok mahasiswa berpengetahuan awal tinggi dan mahasiswa berpengetahuan awal rendah dapat diamati pada Tabel 2.

Tabel 2. Deskripsi Statistik Hasil Belajar Mahasiswa Kelas Eksperimen Berkaitan dengan Pengetahuan Awal

\begin{tabular}{|l|c|c|}
\hline \multirow{2}{*}{ Statistik } & \multicolumn{2}{|c|}{$\begin{array}{c}\text { Kelas Eksperimen } \\
\text { dengan Pengetahuan } \\
\text { Awal }\end{array}$} \\
\cline { 2 - 3 } & Tinggi & Rendah \\
\hline Skor Tertinggi & 100 & 95 \\
\hline Skor Terendah & 80 & 70 \\
\hline Standar Deviasi & 7,99 & 8,45 \\
\hline Mean & 88,13 & 77,5 \\
\hline
\end{tabular}

Adapun nilai rata-rata hasil belajar perkuliahan matematika mahasiswa yang diajar dengan model pembelajaran konvensional dari kelompok mahasiswa berpengetahuan awal tinggi dan mahasiswa berpengetahuan awal rendah dapat diamati pada Tabel 3.

Berdasarkan Tabel 1, 2, dan 3 terlihat bahwa kelas eksperimen memiliki skor total, skor tertinggi dan terendah, serta rata-rata lebih baik dari kelas kontrol. Selanjutnya perlu dilihat 
pada bagian analisis data apakah hasil belajar mahasiswa dengan pengetahuan awal menggu nakan model pembelajaran ROPES dan pembelajaran konvensional berbeda secara statistik atau tidak.

Tabel 3. Deskripsi Statistik Hasil Belajar Mahasiswa Kelas Kontrol Berkaitan dengan Pengetahuan Awal

\begin{tabular}{|l|c|c|}
\hline \multirow{2}{*}{ Statistik } & \multicolumn{2}{|c|}{$\begin{array}{c}\text { Kelas Kontrol dengan } \\
\text { Pengetahuan Awal }\end{array}$} \\
\cline { 2 - 3 } & Tinggi & Rendah \\
\hline Skor Tertinggi & 100 & 80 \\
\hline Skor Terendah & 65 & 55 \\
\hline Standar Deviasi & 13,21 & 11,02 \\
\hline Mean & 74,38 & 67,5 \\
\hline
\end{tabular}

Sebelum analisis data dilakukan, terlebih dahulu diperlukan uji persyaratan analisis. Dari uji persyaratan analisis, didapat hasil uji normalitas dengan menggunakan software minitab bahwa tes hasil belajar mahasiswa kelas eksperimen dan kelas kontrol berdistribusi normal. Selanjutnya dilakukan uji homogenitas variansi. Dengan menggunakan software minitab, didapat bahwa varians tersebut homogen.

Adapun Analisis data dilakukan bertujuan untuk : 1) melihat apakah hasil tes belajar matematika mahasiswa yang diajar dengan model pembelajaran ROPES tinggi diban dingkan dengan mahasiswa yang diajar dengan model pembelajaran konvensional. Berdasarkan hasil analisis menggunakan sofware Minitab, diperoleh $\mathrm{T}$-Value $=3,50$ dan $\mathrm{P}$-Value 0,000 pada $\alpha=0,05$. Dengan demikian dapat dkatakan bahwa hasil belajar matematika mahasiswa yang diajar dengan model pem belajaran ROPES lebih baik dari pada hasil belajar matematika mahasiswayang diajar dengan konvensional. 2) Melihat apakah hasil belajar matematika mahasiswa dengan pengeta huan awal tinggi yang diajar dengan model pembelajaran ROPES lebih tinggi dibandingkan dengan hasil belajar matematikamahasiswa dengan pengetahuan awal tinggi yang diajar dengan konvensional. Berdasarkan perhitungan dengan menggunakan uji-t diperoleh T-Value $=$ 2,52 dan P-Value $=0,014$ pada $\alpha=0,05$. Dengan demikian dapat dikatakan bahwa hasil belajar matematika mahasiswa dengan pengetahuan awal tinggi yang diajar dengan model pembelajaran ROPES lebih tinggi dibandingkan dengan hasil belajar matematika mahasiswa dengan pengetahuan awal tinggi yang diajar dengan konvensional. 3) Melihat apakah hasil belajar matematika mahasiswa dengan pengetahuan awal rendah yang diajar dengan model pembelajaran ROPES lebih tinggi dibandingkan dengan hasil belajar matematika mahasiswa dengan pengetahuan awal rendah yang diajar dengan konvensional. Berdasarkan perhitungan dengan menggunakan uji-t diperoleh $T-$ Value $=2,04$ dan $\mathrm{P}-$ Value $=$ 0,031 pada $\alpha=0,05$. Dengan demikian dapat dikatakan bahwa hasil belajar matematika mahasiswa dengan pengetahuan awal rendah yang diajar dengan model pembelajaran ROPES lebih tinggi dibandingkan hasil belajar matematika mahasiswa dengan pengetahuan awal rendah yang diajar dengan konvensional. 4) Melihat apakah terdapat interaksi antara model pembelajaran dan pengetahuan awal dalam mempengaruhi hasil belajar matematika mahasiswa. Analisis data Anova tentang inter aksi model pembelajaran dengan pengetahuan awal adalah berbeda secara signifikan. Berdasarkan perhitungan dengan menggunakan uji-f, diperoleh $\mathrm{F}$ hitung $=5,68$ lebih besar daripada $F$ tabel alpa 0,05 yaitu 4,17 artinya tidak terdapat interaksi antara model pembelajaran dengan pengetahuan awal dalam mempengaruhi hasil belajar matematika mahasiswa.

Dengan adanya kegiatan yang terstruktur dalam model pembelajaran ROPES, menjadikan Dosen sebagai motivator dan fasilitator sehingga kreatifitas mahasiswa terpancing. Pada kelas eksperimen, pembelajaran yang berlangsung terkesan memotivasi sehingga menjadikan mahasiswa tidak jenuh dengan pembelajaran yang berlangsung. Seluruh rangkaian kegiatan mulai dari review, overview, presentation, exercise, dan summary memancing mahasiswa untuk bersikap aktif dalam pembelajaran. Selain itu, mahasiswa juga diberi kesempatan untuk mengemukakan pendapatnya. Hal ini terlihat dari kegiatan presentation, dimana mahasiswa yang melakukan presentasi menjelaskan materi didepan kelas. Dalam rangkaian kegiatan ini, mahasiswa juga bertanya kepada temannya yang melakukan presentasi dan bebas mengeluarkan pendapat. Hal ini sejalan dengan yang dike mukakan Afgani (2011), guru bukan membekali siswa dengan pengetahuan (learning to know), tetapi membekali siswa dengan cara atau proses mendapatkan pengetahuan (learning to do). Pertanyaan yang tidak terjawab dengan mak simal dijelaskan kembali oleh dosen pada 
kegiatan summary. Penerapan model pem belajaran ROPES dengan optimal mendorong mahasiswa untuk menguasai materi perkuliahan dengan baik sehingga meningkatkan hasil belajar perkuliahan mahasiswa.

Tidak terdapat interaksi antara model pembelajaran dengan pengetahuan awal dalam mempengaruhi hasil belajar perkuliahan mate matika mahasiswa, artinya masing-masing faktor tidak saling ketergantungan dan tidak saling mempengaruhi yang menunjukkan kedua hal tersebut mempunyai posisi sendiri terhadap hasil belajar perkuliahan matematika maha siswa. Sejalan dengan hasil penelitian yang dilakukan oleh Yunus (2012) bahwa variabel model pembelajaran dan pengetahuan awal tidak berinteraksi secara signifikan dalam mem pengaruhi hasil aljabar mahasiswa.

\section{KESIMPULAN}

Hasil penelitian memperlihatkan bahwa : 1) terdapat perbedaan hasil belajar antara mahasiswa yang diajar dengan model pembelajaran ROPES dengan Model pem belajaran konvensional. Perbedaan tersebut menunjukkan bahwa hasil belajar matematika mahasiswa yang diajar dengan model pembelajaran ROPES lebih tinggi dari hasil belajar matematika mahsiswa yang diajar dengan model pembelajaran konvensional. 2) Terdapat perbedaan hasil belajar matematika antara mahasiswa yang berpengetahuan awal tinggi yang diajar dengan model pembelajaran ROPES dengan mahasiswa berpengetahuan awal tinggi diajar dengan model pembelajaran konvensional. Perbedaan tersebut menunjukkan bahwa hasil belajar matematika mahasiswa yang memiliki pengetahuan awal tinggi yang diajar dengan model pembelajaran ROPES lebih tinggi dari hasil belajar matematika mahasiswa yang memiliki pengetahuan awal tinggi diajar dengan model pembelajaran konvensional. 3) Terdapat perbedaan hasil belajar matematika antara mahasiswa yang berpengetahuan awal rendah yang diajar dengan model pembelajaran ROPES dengan mahasiswa berpengetahuan awal rendah diajar dengan model pembelajaran konven sional. Perbedaan tersebut menunjukkan bahwa hasil belajar matematika mahasiswa yang memiliki pengetahuan awal rendah yang diajar dengan model pembelajaran ROPES lebih tinggi dari hasil belajar matematika mahasiswa yang memiliki pengetahuan awal rendah diajar dengan model pembelajaran konvensional. 4) Tidak terdapat interaksi antara model pem belajaran dan pengetahuan awal dalam mem pengaruhi hasil belajar matematika mahasiswa di STIKes Prima Nusantara.

\section{DAFTAR PUSTAKA}

Abdul Madjid. 2013. Perencanaan Pembelajaran. Bandung : PT Remaja Rosdakarya offset.

Afgani, J Dahlan. 2011. Analisis Kurikulum Matematika. Jakarta: Universitas Terbuka

Arief, dkk. 1989. Beberapa Aspek Pengembangan Sumber Belajar. Jakarta: Rineka Cipta.

Depdiknas. 2001. Penyusunan Butir Soal dan Instrumen Penilaian. Jakarta : Depdiknas.

Djamarah. 2004. Strategi Belajar Mengajar. Jakarta: Rineka Cipta

Gagne, Winkel. 1996. Esential of learning for instruction. New York : Holt, Renerhad dan Winston.

2008. Proses Belajar Dan Pembelajaran. Jakarta : Bumi Aksara.

Hamalik,Oemar. 2008. Proses Belajar Mengajar. Jakarta: Bumi Aksara.

Hartono. 2010. Statistik Untuk Penelitian. Yogyakarta : Pustaka Belajar

Muliyardi. 2002. Strategi Pembelajaran Matematika. Padang: Jurusan FMIPA UNP.

Nana Sudjana. 2006. Penilaian Hasil Belajar Mengajar. Bandung : PT. Remaja Rosdakarya.

Saiful Sagala. Konsep dan Makna Pembelajaran. Bandung: CV. Alfabeta.

Slameto. 2008. Metoda Statistika. Bandung : PT. Tarsito Bandung.

Suharsimi Arikunto. 2006. Prosedur Penelitian Suatu Pendekatan Praktek. Jakarta : PT Bina Aksara.

2008. Dasar-dasar Evaluasi Pendidikan. Jakarta : PT Bina Aksara.

Sumadi Suryabrata. 2005. Metodologi Penelitian. Jakarta: PT Raja Grafindo Persada

Syafriandi. (2001). Analisis Statistik Inferensialdengan Menggunakan Minitab.Padang: UNP.

Wina Sanjaya. 2006. Strategi Pembelajaran Berorientasi Standar Proses Pendidikan. Jakarta: Kencana Preanada Media. 